JP3I (Jurnal Pengukuran Psikologi dan Pendidikan Indonesia), 10(I), 202I, 32-38

D0l: http://dx.doi.org/10.15408/jp3i.v10il.18583

http://journal.uinjkt.ac.id/index.php/jp3i

\title{
Study of Perceived Value Instrument in Thesis Writing Using CFA
}

\author{
Ilham Phalosa Reswara, Whisnu Yudiana, Surya Cahyadi \\ Faculty of Psychology, Universitas Padjadjaran, Indonesia \\ surya@unpad.ac.id
}

\begin{abstract}
Perceived value had a major role in an academic activity, including in thesis writing. Unfortunately, there was no study that validated perceived value inventory in the thesis writing setting using empirical evaluation. Thesis writing has specific characteristics that make it unique compared to the general academic activity. Therefore, specific measurement is needed to accurately measure it. The present study aimed to validate the perceived value scale using construct validity approach. The research participants $(\mathrm{N}=219)$ were university students from several faculties. Confirmatory Factor Analysis (CFA) was used to validate the construct. Reliability was also estimated in this study. The result showed that the modified model was fit. The goodness of fit was estimated using Comparative Fit Index (CFI), Root Mean Square Error of Approximation (RMSEA), Goodness-of-Fit Index (GFI), Normed Fit Index (NFI), and NonNormed Fit Index (NNFI). The factor loading of each item was in range of .58 - .87, the Construct Reliability (CR) of each dimension were .81 and .77, and the Average Variance Extracted (AVE) of each dimension were .52 and .54 . The reliability of the whole construct and its factors were satisfying (>.70). This result indicated that this scale was satisfying in overall structure and its convergence.
\end{abstract}

Keywords: perceived value, confirmatory factor analysis, control-value theory of achievement emotions, instrument. 


\section{Introduction}

Constructs about value has been studied for over 80 years (Wigfield et al., 2017). Those studies proved that it played a significant role, positively, in student's emotion (Frenzel et al., 2007; Pekrun, 2017; Pekrun et al., 2011; Pekrun \& Perry, 2015), learning (Artino Jr \& Jones II, 2012; Fardah, 2017; Luo et al., 2016; Marchand \& Gutierrez, 2012; Wigfield et al., 2017), and achievements (Bandura, 1977; Buric \& Soric, 2012; Goetz et al., 2006; Heckhausen \& Heckhausen, 2008; Pekrun et al., 2010; Vogel-Walcutt et al., 2012).

Perceived value relates to the subjective importance of achievement-related activities and outcomes (Pekrun et al., 2011). Perceived value is distinguished into intrinsic values and extrinsic values (Pekrun \& Perry, 2015). Intrinsic values refer to the valuing of the achievement activities or the outcomes themselves, regardless of the consequence (Pekrun \& Perry, 2015). Meanwhile, extrinsic values refer to valuing activities and outcomes because of their instrumental functions for obtaining desired consequences (Pekrun \& Perry, 2015).

Similar to other educational contexts, perceived value also had an important role in thesis writing (Agustiningsih, 2017; Budiono, 2016; Fardah, 2017; Reswara, 2020). Thesis writing has unique characteristics differentiating it from another educational context, which has high task complexity, unstructured schedule, and involves several parties in the process (Cahyadi, 2014; Reswara, 2020). Students with a high perceived value would use more learning strategies in self-regulation which increase their selfregulation (Fardah, 2017). When students perceived thesis writing as something valuable, their hope for succeeding in thesis writing would increase which indirectly increases their self-regulation through the use of learning strategies (Reswara, 2020). Self-regulation itself, which is affected by perceived value (Fardah, 2017), had been proven to affect achievement in thesis writing positively through the use of time in thesis writing (Cahyadi, 2013).

There are several instruments that measure a similar construct to the perceived value which had been used by previous studies (Buil et al., 2016; Hutton et al., 2019; Marchand \& Gutierrez, 2012; Pekrun et al., 2010, 2011). The most popular measurement was MSLQ (Pintrich et al., 1991) that was used in most of the studies (Buil et al., 2016; Hutton et al., 2019; Pekrun et al., 2011). The rest of the studies used their own questionnaire (Marchand \& Gutierrez, 2012; Pekrun et al., 2010). These instruments measured perceived value in a general academic context, meanwhile it would be less relevant to thesis writing context with its unique characteristic. The relevance of the measurement is important and many previous studies created their own questionnaire to measure the value (Marchand \& Gutierrez, 2012; Pekrun et al., 2010).

In Indonesia, the development of perceived value questionnaire designed specifically to measure perceived value in the thesis writing context has been advancing (Budiono, 2016; Fardah, 2017). In the beginning, the questionnaire consisted of 27 items (Budiono, 2016). Then it was shortened by the subsequent study into 6 items (Agustiningsih, 2017; Fardah, 2017). It was validated using content validity evidence, specifically expert judgement (Agustiningsih, 2017; Fardah, 2017), as one of validity testing forms (Kline, 2016).

Until present, there was no evidence-based validity testing that evaluates the goodness of fit between the model of the perceived value construct to the observed variable in the field. This is the limitation of content validity testing as it does not evaluate a questionnaire empirically (Kaplan \& Saccuzzo, 2018; Kline, 2016; Newton \& Shaw, 2014).

The present study aimed to test the perceived value questionnaire using Confirmatory Factor Analysis (CFA) (Hair et al., 2014). This technique facilitates a testing of how well measured variables represent a smaller number of constructs (Hair et al., 2014). 


\section{Methods}

The population in this study was Universitas Padjadjaran students who took thesis subject. It was sampled using two-stage clustered sampling (Nazir, 1998; Ozturk, 2019; Utomo, 2007) based on the scientific cluster in Universitas Padjadjaran, namely social, agro, medical, and science. There were 219 students in the present study. The sample was dominated by female: 148 female students $(63,5 \%)$ and 85 male students (36.5\%). Most students participating in this study were in fourth-year, as many as 203 students (87.1\%), followed by fifth year, third and sixth year, and seventh year, by 14 (6\%), 7 and 7 (3\%), and $2(0.9 \%)$ respectively. The fourth-year students were dominating the sample size because fourth-year is usually when students take their thesis subject for one year. The age average was 21.5 years old $(\mathrm{SD}=0.91$, range 20-25). The Social and Political Faculty was the most dominant with the participation of 86 students (36.5\%), followed by Agriculture Technology and Industry, Psychology, and Geology Technique for 61 (26.2\%), 36 and $36(15.5 \%)$ respectively.

Data collection was conducted using google form. The researcher chose participants randomly using random.org website and spread the questionnaire to their email and WhatsApp number.

The instrument in the present study is based on the previous study (Fardah, 2017) using Likert scale with 5 items in intrinsic value and 3 items in extrinsic values. The five-point Likert Scale is ranging from 1 "sangat tidak sesuai" (very unlikely) to 5 "sangat sesuai" (very likely). Instrument design is explained in Table 2.

Reliability and construct validity were analyzed. Reliability analysis used Cronbach Alpha (American Educational Research Association et al., 2014; Crocker \& Algina, 2008; Hair et al., 2014; Kaplan \& Saccuzzo, 2018; Urbina, 2014) using IBM SPSS 21.00 with minimum satisfying coefficient of .70. Validity construct approach was analyzed using Confirmatory Factor Analysis (Hair et al., 2014; Harrington, 2009). Goodness of fit indicators used in this study are CFI, RMSEA, GFI, NFI, and NNFI (McDonald \& Ho, 2002). CFI, GFI, NFI, and NNFI minimum value is .9 (McDonald \& Ho, 2002). RMSEA under .1 is acceptable (Browne \& Cudeck, 1992; Miskza \& Elpus, 2018). Lisrel 8.80 was used to conduct the Confirmatory Factor Analysis.

\section{Results and Discussion}

Cronbach's alpha from this inventory was .81 which is $>$.7. It is higher than previous studies (.66) (Agustiningsih, 2017; Fardah, 2017). Other similar inventory from previous research measuring similar construct (math value from PISA 2003 and Timms 2007 (Luo et al., 2016), extrinsic utility value scale (Eccles \& Wigfield, 1995), MSLQ (Pintrich et al., 1991)) had similar Cronbach's alpha result, which were .84 (Buil et al., 2016), .70 and .82 (Marchand \& Gutierrez, 2012), .86 (Luo et al., 2016). It indicates items in this inventory could measure the same construct consistently.

Based on confirmatory factor analysis in Table 1., all of the structural criteria of the goodness of fit for this inventory were not fulfilled, meaning the model of the empirical data was not fit with the conceptual model. Possible causes of this result are the wording of the item, the item, or the proposed structure (Brown, 2015), which indicates there could be more (higher order factor) or less factor (a single factor).

Based on Figure 1., every item in each dimension has an acceptable factor loading (> .3) (Chan et al., 2006; Harrington, 2009). Construct reliability (CR) in intrinsic value was .86 and $C R$ in extrinsic value was .83. This $C R$ value ( $>$.7) means there was internal consistency, in which this measurement represented the same latent construct consistently. Therefore, present inventory was not satisfying whether in the overall goodness of fit or in the convergence validity (Hair et al., 2014).

On the other side, average variance extracted (AVE) in intrinsic value was .52, and .31 for extrinsic value. Based on that AVE result, which is $<.5$, average of variance in the items that could be explained by 
the construct was smaller than the error of that item which made its validity questionable (Fornell \& Larcker, 1981; Hair et al., 2014).

However, modification and item droppings were performed in this study. Present study applied the modification indices suggested by the LISREL to increase its model goodness of fit (Brown, 2015). Besides, authors also dropped the item "VALUE5" as its factor loading is significantly lower than .5. The goodness of fit of modified structure is described in Table 1. and it showed that the model was fit.

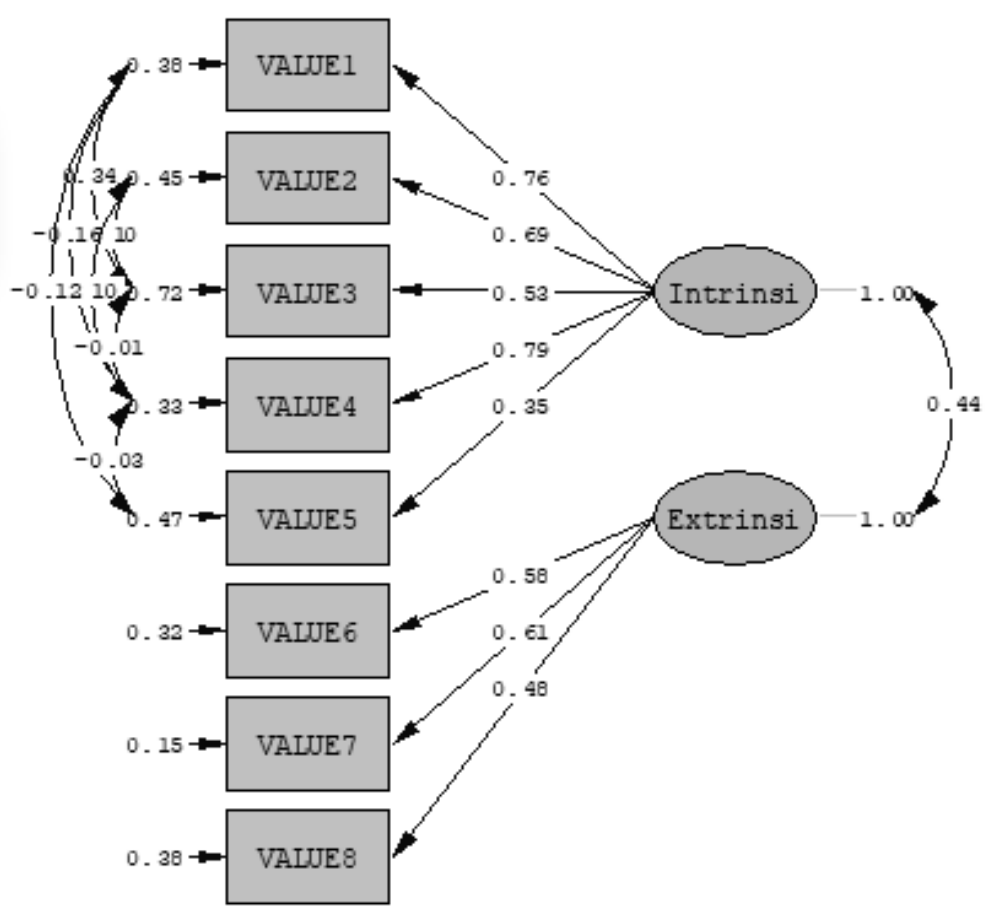

Figure 1. CFA of Perceived Value

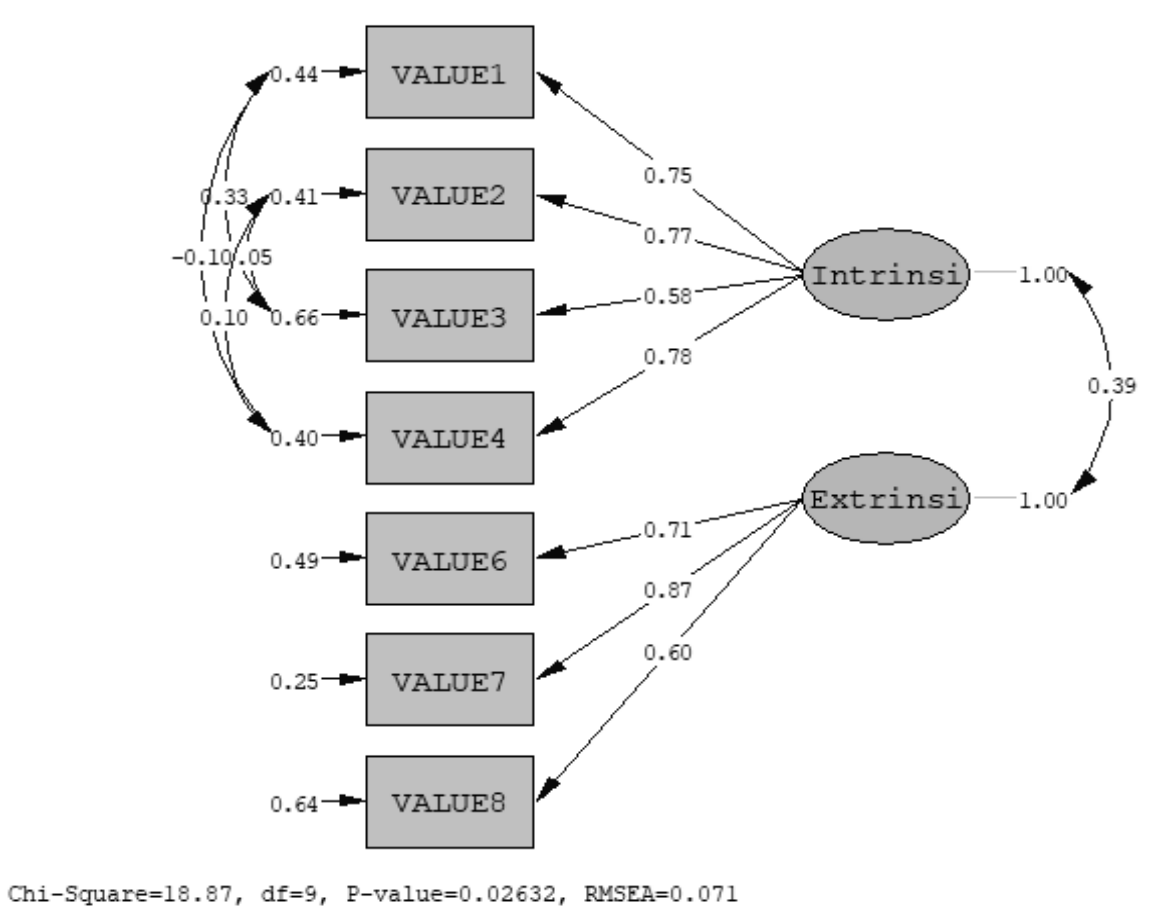

Figure 2. CFA of Perceived Value without Value 5 Item 
Table 1. Result of Goodness of Fit Indexes

\begin{tabular}{lccc}
\hline Goodness of Fit & Criteria & Result & Scale minus Value 5 \\
\hline RMSEA & $<0,1$ & .18 & .071 \\
CFI & $>0,90$ & .88 & .99 \\
GFI & $>0,90$ & .90 & .98 \\
NFI & $>0,90$ & .88 & .98 \\
NNFI & $>0,90$ & .73 & .97 \\
\hline
\end{tabular}

The modification of the model and item also improved the factor loading, AVE and CR. The factor loading of all items exceeded .5, which is categorized as not low (Brown, 2015). The AVE results were .52 and .54 for Intrinsic Value and Extrinsic Value respectively, meaning the indicator was able to explain more variance than the error (Hair et al., 2014). The CR results were .81 and .77 for Intrinsic Value and Extrinsic Value respectively, suggesting that the indicator was consistent enough to measure the same construct (Hair et al., 2014).

There is a limitation in this study. The sample distribution is highly concentrated in the fourth year and as a consequence it could not describe the data evenly form the other years. Therefore, instrument users should be careful in the result interpretation for the overall student population who is conducting their thesis.

\section{Conclusion}

Perceived value inventory was able to measure the construct validly based on the construct validity evidence. The result shows a fit model, whether in the overall fit for the structural or in the convergence fit. In addition, it was consistent enough to measure the construct in the thesis writing context.

There are several suggestions for future studies. Future studies can study another form of validity evidence besides construct validity, such as predictive validity (American Educational Research Association et al., 2014; Hair et al., 2014; Kline, 2016). There was also no comparison between other similar inventory which measure value such as Task Value in MSLQ (Pintrich et al., 1991) or Expectancy-ValueCost (Eccles \& Wigfield, 2002; Kosovich et al., 2015).

\section{References}

Agustiningsih, R. D. (2017). Rancangan intervensi konseling untuk mengubah subjective control dan subjective value pada mahasiswa dengn tingkat engagement pengerjaan skripsi yang rendah. Universitas Padjadjaran.

American Educational Research Association, American Psychological Association, \& National Council on measurement in Education. (2014). Standards for educational and psychological testing. American Educational Research Association.

Artino Jr, A. R., \& Jones II, K. D. (2012). Exploring the complex relations between achievement emotions and self-regulated learning behaviors in online learning. Internet and Higher Education, 15, 170-175. https://doi.org/10.1016/j.iheduc.2012.01.006

Bandura, A. (1977). Self-efficacy: toward a unifying theory of behavorial change. Psychological Review, 84, 191-215. https://doi.org/https://doi.org/10.1037/0033-295x.84.2.191

Brown, T. A. (2015). Confirmatory factor analysis for applied research second edition ( $2^{\text {nd }}$ ed.). The Guilford Press.

Browne, M. W., \& Cudeck, R. (1992). Alternate ways of assessing model fit. Sociological Methods \& Research, 21(2), 230-258. https://doi.org/https://doi.org/10.1177/0049124192021002005 
Budiono, K. D. (2016). Hubungan antara penilaian kognitif dan achievement emotions pada mahasiswa yang sedang menyusun skripsi di Universitas Padjadjaran. Universitas Padjadjaran.

Buil, I., Catalan, S., \& Martínez, E. (2016). Do clickers enhance learning? A control-value theory approach. Computers \& Education, 103, 170-182. https://doi.org/10.1016/j.compedu.2016.10.009

Buric, I., \& Soric, I. (2012). The role of test hope and hopelessness in self-regulated learning: Relations between volitional strategies, cognitive appraisals and academic achievement. Learning and Individual Differences, 22, 523-529. https://doi.org/10.1016/j.lindif.2012.03.011

Cahyadi, S. (2013). Model prestasi dalam pengerjaan skripsi terkait dengan peran achievement emotion dan selfregulation pada mahasiswa psikologi di Bandung. Universitas Padjadjaran.

Cahyadi, S. (2014). Peran emosi terhadap self-regulation mahasiswa dalam pengerjaan skripsi. Indonesian Journal of Applied Science, 4(2), 42-47. https://doi.org/https://doi.org/10.24198/.v4i2.16805

Chan, Y. C., Lam, G. L. T., Chun, P. K. R., \& So, M. T. E. (2006). Confirmatory factor analysis of the child abuse potential inventory: results based on a sample of Chinese mothers in Hong Kong. Child Abuse \& Neglect, 30, 1005-1016. https://doi.org/https://doi.org/10.1016/j.chiabu.2006.05.005

Crocker, L., \& Algina, J. (2008). Introduction to classical and modern test theory. Cengage Learning.

Eccles, J. S., \& Wigfield, A. (1995). In the mind of the actor: the structure of adolescents' achievement task values and expectancy-related beliefs. Personality and Social Psychology Bulletin, 21(3), 215-225. https://doi.org/https://doi.org/10.1177/0146167295213003

Eccles, J. S., \& Wigfield, A. (2002). Motivational beliefs,values, and goals. Annual Review, 53(53), 109132. https://doi.org/https://doi.org/10.1146/annurev.psych.53.100901.135153

Fardah, N. N. (2017). Model empirik keterkaitan subjective control, subjective value, dan anxiety dalam memengaruhi self-regulation mahasiswa pada pengerjaan skripsi. Universitas Padjadjaran.

Fornell, C., \& Larcker, D. F. (1981). Evaluating structural equation models with unobservable variables and measurement error. Journal of Marketing Research, 18(1), 39-50. https://doi.org/https://doi.org/10.1177/002224378101800104

Frenzel, A. C., Pekrun, R., \& Goetz, T. (2007). Girls and mathematics - A "hopeless" issue? A controlvalue approach to gender differences in emotions towards mathematics. European Journal of Psychology of Education, 22(4), 497-514. https://doi.org/https://doi.org/10.1007/bf03173468

Goetz, T., Pekrun, R., Hall, N., \& Haag, L. (2006). Academic emotions from a socio-cognitive perspective: Antecedents and domain specificity of students' affect in the context of Latin instruction. British Journal of Educational Psychology, 76, 289-308. https://doi.org/https://doi.org/10.1348/000709905x42860

Hair, J. F., Black, W. C., Babin, B. J., \& Anderson, R. E. (2014). Multivariate data analysis (7 $7^{\text {th }}$ ed.). Pearson Prentice Hall.

Harrington, D. (2009). Confirmatory factor analysis. Oxford University Press.

Heckhausen, J., \& Heckhausen, H. (2008). Motivation and action. Springer-Verlag.

Hutton, E. A., Skues, J. L., \& Wise, L. Z. (2019). Using control-value theory to predict completion intentions in vocational education students. International Journal of Training Research, 17(2), 157-175. https://doi.org/10.1080/14480220.2019.1638615

Kaplan, R. M., \& Saccuzzo, D. P. (2018). Psychological testing principles, applications, \& issues (9 ${ }^{\text {th }}$ ed.). Cengage Learning.

Kline, R. B. (2016). Principles and practice of structural equation modeling ( $4^{\text {th }}$ ed.). The Guilford Press.

Kosovich, J. J., Hulleman, C. S., Barron, K. E., \& Getty, S. (2015). A practical measure of student motivation: establishing validity evidence for the expectancy-value-cost scale in middle school. Journal of Early Adolescence, 35(5-6), 790-816. https://doi.org/10.1177/0272431614556890 
Luo, W., Ng, P. T., Lee, K., \& Aye, K. M. (2016). Self-efficacy, value, and achievement emotions as mediators between parenting practice and homework behavior: A control-value theory perspective. Learning and Individual Differences, 50, 275-282. https://doi.org/10.1016/j.lindif.2016.07.017

Marchand, G. C., \& Gutierrez, A. P. (2012). The role of emotion in the learning process: Comparisons between online and face-to-face learning settings. Internet and Higher Education, 15(3), 150-160. https://doi.org/10.1016/j.iheduc.2011.10.001

McDonald, R. P., \& Ho, M.-H. R. (2002). Principles and practice in reporting structural equation analyses. Psychological Methods, 7(1), 64-82. https://doi.org/https://doi.org/10.1037/1082989x.7.1.64

Miskza, P., \& Elpus, K. (2018). Design and analysis for quantitative research in music education. Oxford University Press.

Nazir, M. (1998). Metode penelitian. Ghalia Indonesia.

Newton, P. E., \& Shaw, S. D. (2014). Validity in educational \& psychological assessment. Sage publications.

Ozturk, O. (2019). Two-stage cluster samples with ranked set sampling designs. Annals of the Institute of Statistical Mathematics, 71, 63-91. https://doi.org/10.1007/s10463-017-0623-z

Pekrun, R. (2017). Achievement emotions. In A. J. Elliot, C. S. Dweck, \& D. S. Yeager (Eds.), Handbook of competence and motivation theory and application ( $2^{\text {nd }}$ ed., pp. 251-271). The Guilford Press.

Pekrun, R., Goetz, T., Daniels, L. M., Stupnisky, R. H., \& Perry, R. P. (2010). Boredom in achievement settings: exploring control-value antecedents and performance outcomes of a neglected emotion. Journal of Educational Psychology, 102(3), 531-549. https://doi.org/10.1037/a0019243

Pekrun, R., Goetz, T., Frenzel, A. C., Barchfeld, P., \& Perry, R. P. (2011). Measuring emotions in students' learning and performance: The Achievement Emotions Questionnaire (AEQ). Contemporary Educational Psychology, 36(1), 36-48. https://doi.org/10.1016/j.cedpsych.2010.10.002

Pekrun, R., \& Perry, R. P. (2015). Control-value theory of achievement emotions. International Handbook of Emotions in Education, 11531. https://doi.org/10.4324/9780203148211.ch7

Pintrich, P. R., Smith, D. A. F., Garcia, T., \& McKeachie, W. J. (1991). A manual for the use of the learning questionnaire motivated strategies for (MSLQ). University of Michigan.

Reswara, I. P. (2020). Peran hope sebagai mediator dalam pengaruh control appraisals dan value appraisals terhadap self-regulation dalam pengerjaan skripsi mahasiswa Unpad. Universitas Padjadjaran.

Urbina, S. (2014). Essentials of Psychological Testing (2nd ed.). Wiley.

Utomo, A. P. (2007). Kajian tentang pengaruh two stage cluster sampling terhadap statistik uji-F. Jurnal $\begin{array}{lllll}\text { Matematika, Sains, } & \text { dan }\end{array}$ https://jurnal.ut.ac.id/index.php/jmst/article/download/625/612

Vogel-Walcutt, J. J., Fiorella, L., Carper, T., \& Schatz, S. (2012). The definition, assessment, and mitigation of state boredom within educational settings: A comprehensive review. Educational Psychology Review, 24, 89-111. https://doi.org/https://doi.org/10.1007/s10648-011-9182-7

Wigfield, A., Rosenzweig, E. Q., \& Eccles, J. S. (2017). Achievement values interactions, interventions, and future directions. In A. J. Elliot, C. S. Dweck, \& D. S. Yeager (Eds.), Handbook of Competence and Motivation Theory and Application (2nd ed., pp. 116-134). The Guilford Press. 